\title{
STRATEGI PENGEMBANGAN SALAK PONDOH PRONOJIWO KABUPATEN LUMAJANG
}

Oleh :

SRI HASTUTI *)

\begin{abstract}
ABSTRAK
Salak yang merupakan salah satu buah eksotis yang dimiliki Indonesia, apalagi Salak Pronojiwo Kabupaten Lumajang yang memiliki karakteristik berbasis kawasan yang justru lebih baik dibandingkan dengan asal bibitnya yaitu salak pondoh Sleman - Yogyakarta, diantaranya : buah lebih besar, lebih berair, rasanya sama-sama tidak ada pahit/sepetnya walaupun masih muda, lebih manis dan ada sedikit asamnya sehingga rasanya lebih segar. Dengan kondisi demikian, maka salak pondoh Pronojiwo layak untuk dikembangkan dalam rangka menunjang program Pemerintah Kabupaten Lumajang yang digariskan dalam rencana strategis Dinas Pertanian yang terdiri dari program peningkatan ketahanan pangan, pengembangan agribisnis dan Program Peningkatan Kesejahteraan Petani.

Hasil penelitian menunjukkan bahwa dalam lima tahun terakhir (2006 - 2010) menunjukkan bahwa Perkembangan luas Tanam, Luas Panen, Produktivitas dan Produksi Salak Pondoh di Kecamatan pronojiwo Kab Lumajang mengalami perkembangan yang signifikan, yaitu rata-rata kenaikannya sebesar $21,25 \%$ tiap tahunnya. Dengan mempergunakan analisis SWOT, hasil penelitian menunjukkan bahwa faktor-faktor internal maupun eksternal yang mempengaruhi terhadap pengembangan salak di Kabupaten Lumajang antara lain: kekuatan : Sumber daya lahan, kelembagaan kelompok tani, pemasaran hasil, lokasi sentra, sumberdaya manusia, varietas salak, komoditas tropis; kelemahan: Produksi, bibit, pemupukan berimbang, alat penyimpan buah, manajemen usahatani, permodalan, luas areal salak, kontinyuitas produksi; peluang: Paket teknologi, kebijakan pemerintah, lembaga perkreditan dan Infrastruktur jalan; dan ancaman: penangkaran bibit, agroindustri, pesaing dan transportasi. Dari kondisi tersebut, maka strategi yang sesuai adalah strategi agresif, yaitu yaitu kegiatan untuk memperluas perusahaan dengan cara membangun lokasi yang lain, dan meningkatkan jenis produk serta jasa. Perusahaan dapat memperluas pasar, fasilitas produksi dan teknologi melalui pengembangan internal maupun eksternal.

Untuk itu, maka pembinaan teknis petani melalui penyuluhan khususnya magang, teknik penelitian sampai pengepakan bagi petani dan pedagang perlu ditingkatkan terus menerus. Selain itu perlu adanya sistem informasi pasar yang dapat diketahui oleh pelaku agribisnis salak, terutama mengenai harga yang sedang berlaku pada daerah tertentu serta meningkatkan kemampuan pelaku agribisnis salak melalui pengembangan kemampuan tehnis dan berorganisasi, sehingga mempunyai kemampuan untuk mengembangkan usaha dengan kreatifitas dan inovasi yang tinggi
\end{abstract}

Kata kunci : Strategi, Pengembangan, Salak Pondoh Pronojiwo. 



\section{PENDAHULUAN}

\subsection{Latar Belakang}

Salak yang merupakan salah satu buah eksotis yang dimiliki Indonesia, memiliki peluang pasar yang sangat menggiurkan. Dengan bentuk dan rasa yang kas, salak merupakan salah satu komoditi yang layak untuk dikembangkan. Salah satu jenis salak adalah salak pondoh. Salak pondoh adalah fenomenal. Mulai dikembangkan pada kira-kira tahun 1980an, salak yang manis dan garing ini segera menjadi buah primadona yang penting di wilayah DIY. Tahun 1999, produksi buah ini di Yogyakarta meningkat $100 \%$ dalam lima tahun, mencapai 28.666 ton. Kepopuleran salak pondoh di lidah konsumen Indonesia tak lepas dari aroma dan rasanya, yang manis segar tanpa rasa sepat, meski pada buah yang belum cukup masak sekalipun. (Wijaya dkk, 2005). Gambaran produksi itu jelas memperlihatkan lonjakan pesat dari tahun-tahun sebelumnya. Perkiraan produksi salak di seluruh Jawa sampai tahun 1980an hanya berkisar antara 7.000 - 50.000 ton, dengan wilayah Jawa Barat menyumbang kurang lebih setengah dari jumlah itu (Verheijdan Coronel (eds.). 1997).

Kini perkebunan salak pondoh telah meluas ke mana-mana, seperti ke wilayah Wonosobo, Banjarnegara, Banyumas, Kuningan dan lain-lain. Salah satu daerah yang mengembangkan salak pondoh adalah Kecamatan Pronojiwo di Kabupaten Lumajang. Salak Pronojiwo - Lumajang yang memiliki karakteristik berbasis kawasan yang justru lebih baik dibandingkan dengan asal bibitnya yaitu salak pondoh Sleman - Yogyakarta, diantaranya : buah lebih besar, lebih berair, rasanya sama-sama tidak ada pahit/sepetnya walaupun masih muda, lebih manis dan ada sedikit asamnya sehingga rasanya lebih segar.

Berdasarkan data statistik pertanian tahun 2008, jumlah pohon salak di Kabupaten Lumajang sebesar 539.147 pohon. Di Pronojiwo sebesar 228.200 pohon. Produksi total sebesar 360.046 kuintal. Salak Pronojiwo sebesar 154.862 kuintal (Dinas Pertanian Kabupaten Lumajang, 2010). Luas areal tanam salak Pronojiwo 565 ha, yang sudah berproduksi sekitar $70 \%$ nya dengan produktivitas rata-rata 80 kuintal/ha per tahun, sedangkan potensinya bisa mencapai $200-300$ ton/ha per tahun. Seiring dengan bertambahnya tanaman yang berproduksi dan meningkatnya produktivitas, semakin tahun produksinya semakin meningkat. Sedang pemasarannya masih ditingkat domestik. Padahal informasi dari Dinas Pertanian Kabupaten Lumajang, ketika ada calon Pembeli (Bayer) dari Swiss ketika diajak ke lokasi dan mencicipi buahnya sangat tertarik, sehingga tinggal peningkatan kualitas dan mempersiapkan kuantitas dan kontinyuitas.

\subsection{Rumusan Masalah}

Berdasarkan uraian di atas, untuk mengetahui prospek pengembangan salak Pronojiwo Lumajang, maka dibuatlah rumusan masalah sebagai berikut:

a.Bagaimana perkembangan salak Pronojiwo Lumajang, dan bagaimana peluang pengembangan salak Pronojiwo Lumajang tersebut di era ASEAN-China Free Trade Area.

b.Faktor-faktor apa saja yang mempengaruhi pengembangan salak Pronojiwo Lumajang ditinjau dari sisi kekuatan (strengths) dan kelemahan (weaknesses) serta peluang (opportunities) dan ancaman (threats).

c. Strategi apa yang sesui untuk diterapkan dalam pengembangan salak Pronojiwo Lumajang.

\subsection{Tujuan Penelitian}

Berdasarkan latar belakang dan rumusan masalah pokok di atas maka penelitian ini bertujuan untuk :

a.Mengetahui perkembangan salak Pronojiwo Lumajang dan peluang pengembangan salak Pronojiwo Lumajang tersebut di era ASEAN-China Free Trade Area.

b.Mengetahui faktor-faktor yang mempengaruhi pengembangan salak Pronojiwo Lumajang ditinjau dari sisi kekuatan (strength) dan kelemahan (weakness) serta peluang (opportunity) dan ancaman (treths)

c. Menentukan strategi yang sesuai untuk pengembangan salak Pronojiwo Lumajang.

\subsection{Kegunaan Penelitian}

Dari tulisan pengembangan salak Pronojiwo Lumajang ini diharapkan:

a. Dapat dipakai sebagai bahan pertimbangan dalam menyusun strategi serta kebijakan pengembangan hortikultura khususnya salak.

b. Dapat berguna bagi pelaku/petani hortikultura, khususnya petani salak.

c. Dapat bermanfaat bagi para peneliti dibidang pengembangan hortikultura khususnya di bidang salak.

\section{TINJAUAN PUSTAKA}

\subsection{Hasil Penelitian Terdahulu}

Sumbangan ekspor komoditi hortikultura Jawa Timur masih kecil dibandingkan dengan ekspor non migas yang lainnya, seperti tanaman pangan, perkebunan, perikanan dan lain 
sebagainya. Rata-rata peranan sektor tanaman pangan terhadap sektor non migas dari tahun 1988 sampai dengan 1991 sebesar 6,585\%, perkebunan $11,56 \%$, peternakan sebesar $0,915 \%$ sedangkan untuk hortikultura 0,07\%. (Helmi Desieni, 1993).

Menurut Widyastuti dan Paimin (1993), sebagai buah asli Indonesia salak mempunyai prospek cukup cerah. Masyarakat Indonesia menyukai buah ini sehingga konsumsi salak untuk pasar lokal cukup tinggi bahkan meskipun dalam volume yang masih terbatas, buah tropis ini sudah menembus pasar luar negeri. Oleh karena itu pemerintah menetapkan buak salak sebagai salah satu komoditi yang mendapat prioritas untuk ditingkatkan nilai ekspornya.

$$
\text { Selanjutnya Winarno }
$$

mengemukakan bahwa dengan meningkatnya pendapatan dan kesejahteraan masyarakat, tentu akan meningkatkan preferensi masyarakat terhadap buah-buahan, antara lain melalui tuntutan kualitas. Pengembangan buah-buahan memerlukan adanya penyebaran yang terarah dan seksama. Oleh karena itu pendekatan yang dilaksanakan dalam strategi pengembangan buahbuahan ini melalui pembentukan sentra dengan menciptakan kawasan-kawasan sentra produksi yang disadari merupakan salah satu upaya yang bermanfaat dalam usaha menuju industri hortikultura dimasa mendatang.

Menurut Nazarudin dan Kristiawati (1992) di Indonesia berbagai jenis atau varietas salak telah dikembangkan tetapi hanya beberapa varietas saja yang populer, diantaranya adalah salak pondoh dan salak bali yang rasanya manis seperti gula pasir. Padahal sebenarnya varietas salak lainpun tidak kalah kualitasnya seperti salak Bangkalan yang rasanya manis dan beraroma harum.

\subsection{Landasan Teori \\ 2.2.1. Srategi}

Menurut Rangkuti, F (1999), strategi adalah perencanaan induk komprehensip yang menjelaskan bagaimana perusahaan akan mencapai tujuan yang telah ditetapkan berdasarkan misi yang telah ditentukan sebelumnya.

Menurut Napa (1989), mengartikan strategi adalah satu kesatuan rencana yang komprehensip dan terpadu yang menghubungkan kondisi internal perusahaan dengan situasi lingkungan eksternal agar tujuan perusahaan dapat tercapai.
Strategi memiliki beberapa sifat antara lain : menyatu (Unified) yaitu menyatukan seluruh bagian bagi dalam perusahaan; menyeluruh (Comprehensive) yaitu mencakup seluruh aspek dalam perusahaan ; Integral (Integrated) yaitu seluruh strategi akan cocok / sesuai dengan seluruh tingkatan. Sedangkan karakteristik dari masalah-masalah strategis adalah berorientasi pada masa depan, biasanya berhubungan dengan unit bisnis yang sangat komplek, memerlukan perhatian dari manajemen puncak, akan mempengaruhi kemakmuran jangka panjang dari perusahaan serta melibatkan pengalokasian sejumlah besar sumber daya perusahaan (Wahyudi, 1996).

Menurut Glueck (1984), terdapat empat macam strategi generik yaitu ; strategi stabilitas (stability strategi), strategi ekspansi (expansion strategi), strategi percintaan (refrenchment strategi) dan strategi kombinasi (cobination strategi).

\subsubsection{Strategi Pengembangan Agribisnis}

Strategi pengembangan agribisnis pada pembangunan jangka panjang I yang dikenal dengan strategi kesemestaan, yang lebih diarahkan untuk meningkatkan produksi dan produktifitas pertanian melalui empat usaha pokok; intensifikasi; ekstensifikasi; diversifikasi dan rehabilitasi. Untuk PJP II strategi tersebut sudah tidak lagi memadai karena yang diperlukan adalah tercapainya nilai tambah dan kemampuan bersaing dalam alam pasar terbuka dan globalisasi.

Strategi dasar pengembangan agribisnis di Indonesia adalah pendekatan agribisnis secara terpadu dan berkelanjutan (Anonimous, 1990). Strategi ini tetap bertolak dari kesemestaan agar pertanian yang telah mengalami perubahan posisi (transformasi dari pertanian pedesaan menjadi bagian dari sistem ekonomi nasional) tersebut dapat terus mengembangkan proses retrukturisasi pedesaan, sehingga terdapat keseimbangan sektor ekonomi dari pertanian, industri dan jasa. Dengan strategi ini maka wawasan dan sistem agribisnis akan memperoleh lingkungan strategi yang kondusif bagi pertumbuhan dan perkembangannya.

Untuk tercapainya kondisi lingkungan strategis pengembangan agribisnis yang kondusif dalam jangka retrukturisasi pedesaaan itu perlu dikembangkan empat pilar penopang sistem agribisnis yaitu ; eksistensi semua komponen sistem agribisnis lengkap, wirausaha dan 
kemitraan usaha, iklim lingkungan yang kondusif serta gerakan nasional pembangunan agribisnis .

Kebijakan nasional untuk menumbuh kembangkan agribisnis diarahkan kepada :

1. Pengembangan usahatani melalui pola kemitraan usaha dan kewirausahaan ;

2. Pengembangan kelembagaan agribisnis dipedesaan ;

3. Peningkatan keterkaitan antara sektor pertanian dengan sektor-sektor hilir ;

4. Pengembangan sumberdaya dan sarana agribisnis ;

5. Peningkatan kerjasama organisasi profesi. Selain itu dalam rangka menyebar luaskan pemahaman kepada masyarakat agribisnis yang pada gilirannya akan melahirkan inisiatif dan prakarsa, dikembangkan dan diterapkan Ilmu Pengetahuan Tepat Guna, berkembangnya investasi serta terwujudnya suatu gerakan nasional agribisnis pada tingkat wilayah prioritas kegiatannya diarahkan pada model Kawasan Pengembangan Agribisnis Lokalita (KAPAL).

Dalam tahun 1995 / 1996 juga telah diperkenalkan konsep UPA (Usaha Pengembangan Agribisnis) yang dimaksudkan untuk menumbuh kembangkan usaha-usaha yang bersifat koperatif / usaha kelompok dengan memanfaatkan petugas pertanian sebagai pemandu. UPA diarahkan mampu mengembangkan diri menjadi kelompok usaha koperatif dibidang pelayanan sarana produksi, usaha dibidang budidaya, usaha dibidang pasca panen dan pengolahan hasil serta usaha dibidang pemasaran.

Dijajaran Badan Litbang Pertanian juga dikembangkan pola pengembangan yang disebut INBIS (Intensifikasi Agribisnis) yakni model pengembangan agribisnis yang merupakan kelanjutan Supra Insus yang ditunjang dengan aspek peningkatan prosesing dan pemasaran sehingga prinsip efisiensi dan efektifitas diharapkan dapat dilakukan oleh kelompok tani yang pada akhirnya terdapat peningkatan pendapatan.
Dalam pengembangannya komoditas salak di Kabupaten Lumajang seperti halnya di Jawa Timur pelaksanaannya ditempuh melalui tiga macam pendekatan yaitu:

1. Pendekatan lahan kering ;

2. Pendekatan perwilayahan komoditas ;

3.Pendekatan agribisnis.

\subsubsection{Pengambilan Keputusan Strategi dengan} Analisis SWOT

Proses pengambilan keputusan strategi selalu berkaitan dengan misi, tujuan dan kebijaksanaan perusahaan. Dengan demikian perencanaan strategi harus menganalisa faktorfaktor strategis perusahaan dalam kondisi saat ini. Hal ini disebut dengan Analisa Situasi. Model paling populer untuk menganalisa siatuasi adalah analisa SWOT.

Rangkuti, F (1999), mengartikan analisa SWOT adalah identifikasi berbagai faktor secara sistematis untuk merumuskan strategi perusahaan. Analisa ini didasarkan pada logika yang dapat memaksimalkan kekuatan (strength) dan peluang (opportunities), namun secara bersamaan dapat diminimalkan kelemahan (weaknesses) dan ancaman (threats). Analisa SWOT merupakan ramuan utama perencanaan strategi dan membantu klasifikasi pilihan kebijaksanaan yang dihadapi perusahaan.

Matrik Eksternal Internal menurut Rangkuti (2002) merupakan alat yang dipakai untuk menyusun faktor - faktor strategi perusahaan. Matrik SWOT ini dapat menggambarkan secara jelas bagaimana peluang dan ancaman eksternal yang dihadapi perusahaan dapat disesuaikan dengan kekuatan dan kelemahan internal yang dimiliki 
Tabel 1. Matrik SWOT

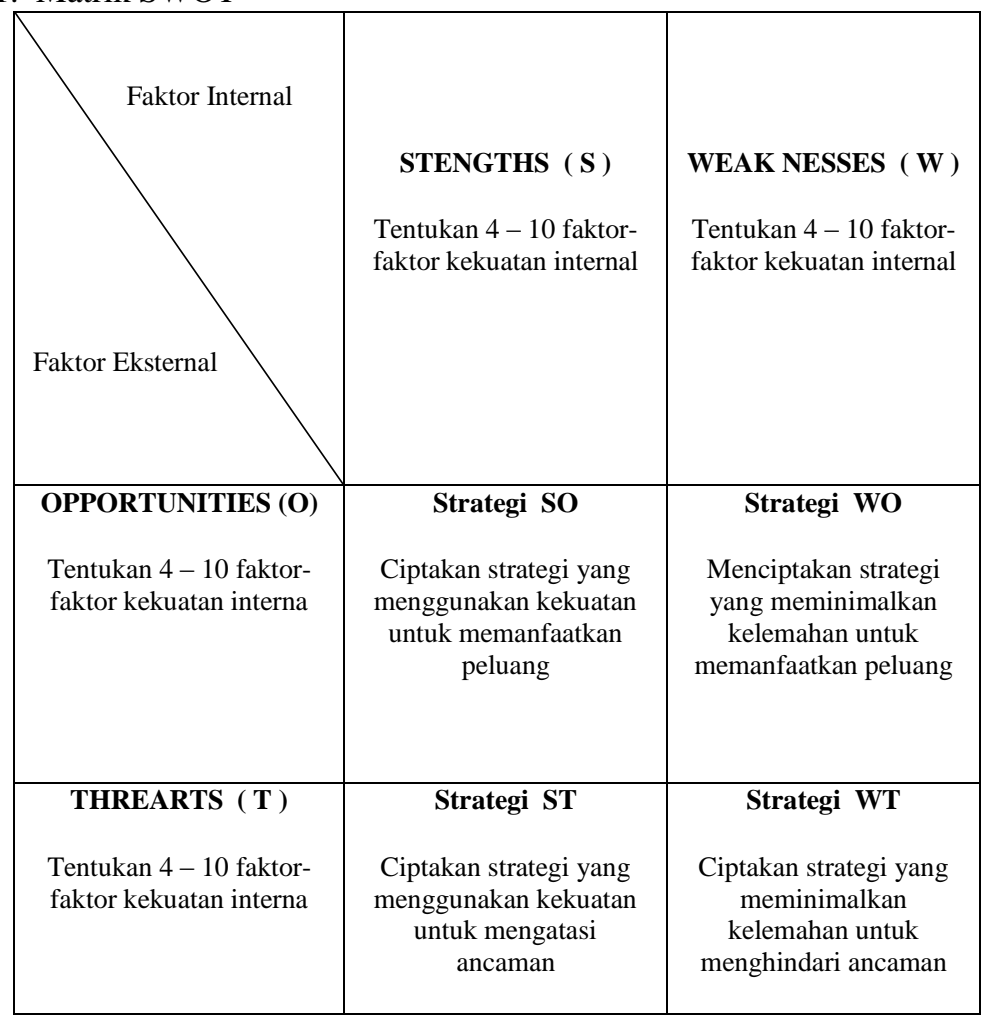

\subsection{Kerangka Pikir}

Dewasa ini, kerangka acuan bagi pembangunan wilayah selalu dikaitkan dengan potensi dan sumber daya untuk dikembangkan secara lebih luas sesuai dengan karakteristik dan kemampuan wilayah bersangkutan. Penggunaan potensi sumber daya dalam proses pembangunan wilayah atau pembangunan daerah merupakan langkah awal yang sangat penting dalam pengembangan agribisnis hortikultura.

Agribisnis hortikultura merupakan salah satu sumber baru disektor pertanian. Secara umum konsepsi pengembangan hortikultura termasuk salak telah mengarah pada sistem agribisnis. Namun dalam penerapan banyak kendala yang dihadapi, sehingga sistem agribisnis secara utuh belum dapat diwujudkan.

Untuk mengembangkan sistem agribisnis yang sesuai dengan visi mewujudkan kemampuan berkompetisi, merespon dinamika perubahan pasar dan pesaing baik dipasar domestik maupun internasional serta meningkatkan kesejahteraan masyarakat maka strategi dan kebijaksanaan yang ada perlu dievaluasi, guna menetapkan perencanaan strategi yang lebih sesuai.

Pendekatan masalah dalam penelitian ini berupa evaluasi kondisi perkembangan agribisnis yang telah dikembangkan khususnya untuk tanaman salak. Kajian dilakukan melalui pendekatan sistem agribisnis dengan titik berat pada sub sistem usahatani, pengolahan dan pemasaran hasil serta sub sistem penunjang.

\section{METODOLOGI PENELITIAN}

\subsection{Waktu dan Lokasi Penetitian}

1. Penelitian ini akan dilaksanakan mulai bulan April sampai dengan Mei 2011.

2. Penelitian dilakukan di Kecamatan Pronojiwo, penetapan lokasi penelitian dengan mempertimbangkan bahwa Kecamatan Pronojiwo merupakan daerah sentra salak di Kabupaten Lumajang. Selain itu, Kecamatan Pronojiwo merupakan daerah yang pertama kali mengembangkan salak pondoh di Kabupaten Lumajang. 


\subsection{Jenis Penelitian}

Penelitian ini merupakan penelitian evaluasi formatif yang dilakukan untuk mengidentifikasi faktor internal dan faktor eksternal yang berpengaruh pada pelaksanaan strategi pengembangan agribisnis salak dilokasi penelitian. Jenis penelitian yang akan dilaksanakan adalah metode studi kasus.

\subsection{Teknik Pengambilan Sampel}

Dalam penelitian ini populasi responden adalah petani salak di Kecamatan Pronojiwo, pedagang salak, petugas pertanian kecamatan dan petugas pertanian kabupaten. Dari jumlah petani yang ada kemudian ditentukan sample dengan menggunakan metode Sample Random Sampling (acak sederhana) sebanyak 40 petani yang diharapkan dapat mewakili dan menjelaskan keseluruhan populasi yang ada.

Metode yang digunakan adalah survei data yang dikumpulkan melalui analisa dokumen; observasi dan wawancara.

Tahapan yang dilakukan dalam rangka mengumpulkan data adalah sebagai berikut :

1. Studi Kepustakaan, yaitu mempelajari buku-buku teks literature, hasil penelitian maupun artikel yang membahas masalah agribisnis serta ekonomi pada umumnya.

$2 . \quad$ Analisa Dokumen, yaitu metode mengumpulkan data dengan cara mempelajari dan menganalisa dokumen dari instansi; Dinas Pertanian Propinsi Jawa Timur, Dinas Pertanian Kabupaten Lumajang, Kantor Urusan Ketahanan Pangan, Dinas Perindustrian dan Perdagangan, Badan Pusat Statistik dan Perpustakaan Pasca Sarjana UNISKA.

3. Pengamatan ( observasi ), dilakukan dilapangan untuk lebih mengetahui kondisi pertanaman maupun permasalahan yang ada di Kecamatan Pronojiwo.

4. Wawancara, dilakukan pada petani produsen salak yang telah disampel.

\subsection{Teknik Pengambilan Data}

Penelitian ini menggunakan 2 (dua) jenis data sebagai bahan pembahasannya, yang meliputi data primer dan skunder. Data primer diperoleh dari jawaban responden dan kondisi fisik dilapangan yang didapatkan saat penelitian yang menyangkut faktor internal maupun eksternal dari obyek penelitian.
Sebagai pendukung indentifikasi faktor internal maupun eksternal, diperlukan data skunder yang diperoleh dari data analisa dokumen yang bersumber dari lembaga terkait seperti Dinas Pertanian, Kantor urusan Ketahanan Pangan dan lain sebagainya.

\subsection{Teknik Analisa Data}

3.6.

Teknik Analisa yang digunakan dalam penelitian ini menggunakan analisis situasi dengan model yang paling populer saat ini yaitu analisis SWOT. Menurut Nugroho, B.A. (2001), bahwa tahapan Analisis SWOT adalah:

1. Mengidentifikasi Visi dan Misi dari institusi.

2. Mengindentifikasi peluang (Opportunities) dan ancaman (Threats).

3. Mendeterminasi faktor kunci keberhasilan (Key Success Factor) untuk memanfaatkan peluang dan menghadapi ancaman.

4. Mengevaluasi kondisi internal (kekuatan dan kelemahan) yang ada dalam perusahaan / organisasi.

Alat yang dipakai untuk menyusun Faktor-faktor strategis adalah matrik SWOT. Matrik ini dapat menggambarkan secara jelas bagaimana peluang dan ancaman eksternal yang di hadapi dapat di sesuaikan dengan kekuatan dan kelemahan internal yang dimiliki.

Dikatakan oleh Rangkuti (2001), bahwa sebelum membuat matrik faktor strategi eksternal terlebih dahulu perlu menentukan External Strategie Faktor Analysis Summary (EFAS)

Demikian juga setelah faktor-faktor strategis internal suatu perusahaan diidentifikasi, suatu tabel Internal Strategie Factors Analysis Summary (IFAS) disusun untuk merumuskan factor-faktor strategis internal tersebut dalam kerangka strength and Weakness perusahaan.

\section{KESIMPULAN DAN SARAN}

\subsection{Kesimpulan}

a. Dalam lima tahun terakhir (2006 - 2010) menunjukkan bahwa Perkembangan luas Tanam, Luas Panen, Produktivitas dan Produksi Salak Pondoh di Kecamatan pronojiwo Kab Lumajang mengalami perkembangan yang signifikan, yaitu ratarata kenaikannya sebesar $21,25 \%$ tiap tahunnya.

b. Faktor-faktor internal maupun eksternal yang mempengaruhi terhadap pengembangan salak di Kabupaten Lumajang antara lain: 
- Faktor Internal

- Kekuatan : Sumber daya lahan, kelembagaan kelompok tani, pemasaran hasil, lokasi sentra, sumberdaya manusia, varietas salak, komoditas tropis.

- Kelemahan :Produksi,bibit, pemupukan berimbang, alat penyimpan buah, manajemen usahatani, permodalan, luas areal salak, kontinyuitas produksi.

- Faktor Eksternal

$$
\begin{gathered}
\text { - Peluang Paket teknologi, } \\
\text { kebijakan pemerintah, } \\
\text { lembaga perkreditan dan } \\
\text { Infrastruktur jalan. } \\
\text { - Ancaman:penangkaranbibit,agroindu } \\
\text { stri, pesaing dan } \\
\text { transportasi. }
\end{gathered}
$$

c. Berdasarkan diagram analisis SWOT posisi pengembangan salak di Kecamatan Pronojiwo pada kuadran I yang berarti Grand Strategy atau Strategi Utama adalah Strategi Agresy, sedangkan berdasarkan matrik internal eksternal berada pada kuadran I yang berarti strategi pengembangan salak di Kecamatan Pronojiwo pada strategi pertumbuhan.

\subsection{Saran}

Guna mengupayakan peningkatan pengembangan agribisnis salak di Kecamatan Pronojiwo, maka disarankan alternatif strategi operasional sebagai berikut :

c. Pembinaan teknis petani melalui penyuluhan khususnya magang, teknik penelitian sampai pengepakan bagi petani dan pedagang perlu ditingkatkan terus menerus. Kursus jangka pendek mengenai arti agribisnis dan teknis pengelolaan usahatani bagi petani salak perlu diselenggarakan.

d. Kegiatan kelompok dalam bentuk sub kelompok tani perlu segera didorong untuk mengefektifkan pelaksanaan alih teknologi, khususnya dalam kemampuan manajemen atau mengelola usaha secara agribisnis.

e. Perlu adanya program peningkatan mutu intensifikasi salak sehingga produksi kualitas, kuantitas maupun kontinyuitas dapat bersaing dipasar dalam maupun luar negeri.

f. Perlu adanya sistem informasi pasar yang dapat diketahui oleh pelaku agribisnis salak, terutama mengenai harga yang sedang berlaku pada daerah tertentu.

g. Meningkatkan daya saing melalui penerapan ilmu pengetahuan dan teknologi serta penerapan manajemen usaha yang profesional.

h. Menumbuhkembangkan agroindustri untuk meningkatkan nilai tambah bagi petani.

i. Meningkatkan kemampuan pelaku agribisnis salak melalui pengembangan kemampuan tehnis dan berorganisasi, sehingga mempunyai kemampuan untuk mengembangkan usaha dengan kreatifitas dan inovasi yang tinggi.

j. Memantapkan pengembangan sentra produksi utamanya dalam menyambut pengembangan program pertanian oleh Pemerintah Kabupaten Lumajang yang digariskan dalam rencana strategis Dinas Pertanian yang terdiri dari program peningkatan ketahanan pangan, pengembangan agribisnis dan Program Peningkatan Kesejahteraan Petani.

\section{DAFTAR PUSTAKA}

Anonimous, (1998) Potensi dan Peluang Investasi Pertanian Tanaman Pangan \& Hortikultura di Jawa Timur. Pusat Promosi dan Informasi. Surabaya.

(2000) Kebijakan dan Program Utama Pembangunan Pertanian Departemen Pertanian Jakarta.

(2004) Pedoman Umum Pengembangan Agribisnis Hortikultura. Departemen Pertanian Jakarta.

(2004). Petunjuk Pelaksanaan Pengembangan Hortikultura di Jawa Timur. Dinas Pertanian Surabaya.

Budipramana, dkk (2000). Pengembangan dan Peningkatan Mutu Salak Madura. Hasil Penelitian Tindakan. Bangkalan.

Desieni Helmi, (1993). Peranan Ekspor Komoditi Hortikultura Terhadap Ekspor Non Migas di Jawa Timur. Skripsi FE. UBAYA Surabaya.

Gueck and Jauch, (1998). Manajemen Strategi dan Kebijaksanaan Perusahaan Terjemahan Murad dan A.R. Henry Sitanggang. Penerbit Erlangga. Jakarta.

H. Wijaya; D. Ulrich; R. Lestari; K. Schippel; and G. Ebert. 2005. Identification of potent odorants in different cultivars of snake fruit [Salacca zalacca (Gaert.) Voss] using gas chromatography- 
olfactometry. J. Agric. Food Chem. 53:5 Hal. 1637-1641

Napa, J.A (1989). Manajemen Strategi Suatu Pendekatan Sistem. Penerbit Liberty. Jogyakarta.

Nazarudin dan Kristiawati, (1992). 18 Varietas Salak, Budidaya, Prospek, Bisnis dan Pemasaran. Penebar Swadaya. Jakarta.

Pusat Data \& Informasi Pertanian Departemen Pertanian Republik Indonesia, database.deptan.go.id akses April 2008

Rangkuti, Freddy, (1999). Analisa Swot - Teknik Membedah Kasus Bisnis. PT. Gramedia Pustaka Utama. Jakarta.

Rukmana R, (1999). Salak Prospek Agribisnis dan Teknik Usahatani. Penerbit Kanisius. Jakarta.

Rustijarno, Sinung.Wiendarti I.W. dan Setyorini $W$. 2007. Pengembangan Agribisnis Salak Pondoh Organik Di Desa Merdikorejo Kecamatan Tempel Kabupaten Sleman Provinsi Daerah Istimewa Yogyakarta: Balai Pengkajian Teknologi Pertanian Yogyakarta
Thamrin, M. 2005. Standar Prosedur Operasional (SPO) dan Good Agricultural Practises (GAP) Pada Budidaya Salak Pondoh. Makalah disampaikan dalam Apresiasi Peningkatan Mutu Salak Melalui Penerapan Standar Prosedur Operasional (SPO) dan Good Agricultural Practises (GAP). Denpasar 6-9 Juni 2005.

Verheij, E.W.M. dan R.E. Coronel (eds.). 1997. Sumber Daya Nabati Asia Tenggara 2: Buah-buahan yang dapat dimakan. PROSEA - Gramedia, Jakarta. Hal 362-366. ISBN 979-511-672-2

Wahyudi, S.A, (1996). Manajemen Strategi Pengantar Proses Berpikir Strategi. Binarupa Aksara. Jakarta.

Widyastuty, Y.E dan F.B. Paimin, (1993). Mengenal Buah Unggul Indonesia. Penebar Swadaya. Jakarta.

Winarno, (1996). Strategi Pengembangan Produksi Buah-Buahan Untuk Pasar Domestik. Majalah Pangan No. 26 Vol. VIII. Jakarta. 